\title{
Effect of Monocrotophos, an Organophosphorus Pesticide on the Growth of Tadpoles of Limnonectis Limnocharis, a Rice Field Frog
}

\author{
Sanjay Kumar Swain, Malaya Ranjan Mahananda* \\ Department of Environmental Sciences, Sambalpur University, Odisa -768019, India \\ *Corresponding Author: malaya_env@rediffmail.com
}

Copyright (C) 2014 Horizon Research Publishing All rights reserved.

\begin{abstract}
The effect of monocrotophos an organophosphorus insecticide on the growth of tadpoles of a dominant rice field anuran species (Limnonectis limnocharis) was studied. Prior to growth experiment a $96 \mathrm{~h}$ toxicity test was conducted in different concentrations of monocrotophos to calculate $\mathrm{LC}_{50}$ value by probit analysis. The $96 \mathrm{~h}$ of $\mathrm{LC}_{50}$ value for the tadpoles was found to be $0.59 \mathrm{mg} \mathrm{l}$. Based on the result of toxicity test and recommended field agricultural dose $\left(0.60 \mathrm{mg} \mathrm{^{- }}\right)$ three sublethal concentration of monocrotophos were taken to study the growth of three days old tadpoles up to metamorphic climax stage and it was compared with that of the controls. Analysis of data revealed that after 35 days the length and body weight of tadpoles decreased by $7.8,13$ and $21.4 \%$ and by $6.03,6.74$ and $8.8 \%$ in $0.25,0.30$ and $0.35 \mathrm{mg} \mathrm{l}^{-}$respectively from the control condition. The decrease in length and body weight of tadpoles also caused increase in duration of metamorphosis. The metamorphic climax was reached after 38, 41 and 44 days in $0.25,0.30$ and $0.35 \mathrm{mg} \mathrm{l}^{-}$monocrotophos respectively, instead of 35 days in control condition. The above results indicates that application of pesticides even below the recommended dose cause ecological problems and non target beneficial species are victimized. This finding supports that organic farming and controlled use of pesticides for conservation of frogs in the paddy field.
\end{abstract}

Keywords Limnonectis Limnocharis, Tadpole, Growth, Metamorphosis, Monocrotophos

\section{Introduction}

Paddy (Rice) is the most important cereal crop of the world [1]. In India paddy is cultivated in about $22 \%$ of the gross cropped area. It covers about $47 \%$ of the gross cropped area in Orissa state [2]. The major insect pests and related diseases are culminated in paddy during the rainy to early winter period i.e. from July to November. A diversity of pesticides and their residues have been recorded in a wide variety of aquatic habitats [3] exposing the inhabitants to these harmful substances Organophosphorous insecticides are less persistence and toxic than organochlorine and carbamate type insecticides. But they also create several problems like others, which lead to the imbalance in the ecosystem [4].The two most important problems are: (i) some of the pest organisms particularly the insects have developed resistance to the chemicals. (ii) Non-target beneficial organisms like frog, bird and earthworm etc.[5-7] are also affected by the pesticides.

Amphibians are integral component of many ecosystem and they may constitute the highest fraction of vertebrate biomass in some ecosystems [8] and occupy a critical position in the ecological pyramid, as they are major predators of insect and other pest [9-10]. Because of their beneficial role, especially from agricultural point of view they are often refer to as "farmer's friend". A decline in amphibian population can have an adverse effect in agriculture and other areas. It is generally believed that increasing use of pesticides and fertilizers are one f the major causes responsible for depletion of the population of anurans all over the world $[7,11]$. There have been numerous reports suggesting that the populations of anuran species in a wide array of geographical regions and habitats have apparently declined or have experienced range reductions by adverse effects of pesticides [12-14].

The most of the paddy fields of Orissa, the organophophorous insecticides particularly monocrotophos, malathion, phorate and fenitothion are commonly used against the insecticide pests. The amphibian species generally seen in paddy fields of Orissa are as follows: Limnonectis limnocharis, Haplobatrachus tigerinus and Euphlyctis cyanophlyctis [11].Among these Limnonectis limnocharis is the dominant species followed by Euphlyctis cyanophlyctis and Haplobatrachus tigerinus. Basing on the above fact the present work was undertaken to study the effect of a widely used organophosphorus insecticide (monocrotophos) on the tadpoles of a dominant anuran species (Limnonectis limnocharis) found in the paddy fields of Orissa. 


\section{Materials and Methods}

Amicron 36\% SL, a trade name of monocrotophos, manufactured by All India Medica Corporation, Noroda, Ahmedabad, India was selected as the test chemical in the present investigation. It is a water soluble concentrate containing 36\% w/w, 0-0-dimethyl-0(2 methyl carbonyl-1 methyl-vinyl) phosphate. It is a contact insecticide and acaricide, effective against sucking, chewing and manning type of insect pests (thrips, aphides, mites, scales, borers, caterpillars, beetles and hoppers) of crops like paddy, maize, sugarcane, cotton, gram etc.

The recommended field agricultural dose of monocrotophos for paddy crops as provided in the leaflet specification is $1250 \mathrm{ml}$ formulation diluted to $750 \mathrm{~L}$ of water sprayed to over an area of one hectare. This is equivalent to $1.67 \mathrm{ml} \mathrm{l}^{-}$formulations or $0.60 \mathrm{mg} \mathrm{l}^{-}$active ingredient of monocrotophos. Basing on this recommended rate, toxicity test on tadpoles (larvae) of Limnonectis limnocharis was conducted in different concentrations of monocrotophos. For this experiment plastic dishes of 40x 30x $25 \mathrm{~cm}$ size having $5 \mathrm{~L}$ capacity was used. The various concentrations of monocrotophos used were $0.1,0.2,0.3,0.4,0.5,0.6,0.7,0.9$ $\mathrm{mg} \mathrm{l}^{-}$. These concentrations were prepared using appropriate volume of conditioned water. For each concentration three replicates of above sized plastic dishes having three liters of respective concentration were kept and in each replicate twenty tadpoles ( 3 day old) were kept. The larvae were fed every day with adequate amount of mixed food diet consisting of boiled Amaranthus tricolour leaves, chicken egg yolk and cooked minced goat meat in a ratio of $5: 1: 1$ [15]. During the test period the tadpoles from each replicate were transferred to other containers having freshly prepared respective concentrations of monocrotophos. Mortality was recorded daily during the time of transfer and it was continued for 4 days. After 4 days $\mathrm{LC}_{50}$ value was calculated from the mortality data using Finney's probit analysis [16].On the basis of the recommended agricultural dose and $\mathrm{LC}_{50}$ value obtained, three sublethal concentrations of monocrotophos $\left(0.25,0.30\right.$ and $\left.0.35 \mathrm{mg} \mathrm{l}^{-}\right)$was chosen to study its effect on larval development. Egg masses of Limnonectis limnocharis were collected from the nearby paddy field having no history of pesticides application during early part of monsoon and maintained in the laboratory using habitat water at $25 \pm 2^{\circ} \mathrm{C}$. The tadpole hatched out from the eggs was used for the study.

The sublethal concentrations $\left(0.25,0.30\right.$, and $\left.0.35 \mathrm{mg} \mathrm{l}^{-1}\right)$ of monocrotophos were prepared using appropriate volume of conditioned water and control $\left(0.0 \mathrm{mg} \mathrm{l}^{-}\right)$was prepared using only conditioned water as suggested by Nace and Richards [17].Three liter of each concentration were kept in plastic dishes $(40 \times 30 \times 25 \mathrm{~cm})$ in five replicates. To each replicate five 3 day old tadpoles of approximately equal size and weight were left. The initial length and body weight were measured. The tadpoles were given every day with adequate amount of mixed diet [15].On every alternate day the tadpoles from each replicate were transferred to another container having freshly prepared respective concentrations of monocrotophos. During the time of transfer, the tadpole growth was measured in terms of body weight and length and emergence of fore limbs, hind limbs and deformation of body, if any was examined.

\section{Results}

\subsection{Toxicit Test}

The mortality data after exposure of 3 days old tadpoles of Limnonectis limnocharis to various concentrations of monocrotophos for $96 \mathrm{~h}$ were used to calculate $\mathrm{LC}_{50}$ value by probit analysis. It was observed that tadpoles of $L$. limnocharis, could not survive beyond $96 \mathrm{~h}$ in $1.0 \mathrm{mg} \mathrm{l}^{-}$of monocrotophos, where as tadpoles did not die upto $0.1 \mathrm{mg} \mathrm{l}^{-}$. The $\mathrm{LC}_{50}$ value with its $95 \%$ confidence limit for $L$. limnocharis tadpoles came to be $0.59 \mathrm{mg} \mathrm{l}^{-}\left(0.48-0.72 \mathrm{mg} \mathrm{l}^{-}\right)$ (Table 1).

Table 1. 96hr toxicity test of 3 days old Lminonectis limnocharis tadpoles at different concentrations of monocrotophos

\begin{tabular}{|c|c|c|c|c|c|c|}
\hline $\begin{array}{c}\text { Conc. Of } \\
\text { Monocrotophos(ppm) }\end{array}$ & $\begin{array}{c}\% \text { of } \\
\text { Mortality }\end{array}$ & $\begin{array}{c}\text { Log(+1) } \\
\text { dose }\end{array}$ & $\begin{array}{c}\text { Experical } \\
\text { probit }\end{array}$ & $\begin{array}{c}\text { Expected } \\
\text { probit }\end{array}$ & $\begin{array}{c}\text { Working } \\
\text { probit }\end{array}$ & $\begin{array}{c}\text { LC } 50 \text { conc. } \\
\text { arrived from graph }\end{array}$ \\
\hline 0.0 & 0 & - & - & - & - & \\
\hline 0.1 & 0 & 0.00 & - & - & - & \\
\hline 0.2 & 1.0 & 0.30 & 1.85 & 2.10 & 3.467 & \\
\hline 0.3 & 20.0 & 0.50 & 4.15 & 3.94 & 4.195 & \\
\hline 0.4 & 56.0 & 0.60 & 5.15 & 5.52 & 5.127 & \\
\hline 0.5 & 88.0 & 0.70 & 6.25 & 6.00 & 6.160 & \\
\hline 0.6 & 98.0 & 0.80 & 7.07 & 6.85 & 7.033 & $0.59 \mathrm{ppm}$ \\
\hline 0.7 & 99.4 & 0.85 & 7.52 & 7.40 & 7.319 & \\
\hline 0.8 & 99.8 & 0.90 & 7.82 & 7.65 & 7.073 & \\
\hline 0.9 & 99.9 & 0.95 & 8.04 & 8.80 & 100.0 & \\
\hline 1.0 & 100.0 & 1.00 & - & - & - & \\
\hline
\end{tabular}




\subsection{Growth of Tadpoles}

On the basis of toxicity test the recommended agricultural dose, three sublethal $\left(0.25,0.30\right.$, and $\left.0.35 \mathrm{mg} \mathrm{l}^{-}\right)$ concentrations of monocrotophos were chosen. Effect of these three concentrations on the length and body weight of $L$. limnocharis, larvae during metamorphosis were studied and compared with controlled condition. The results of the study are presented in Table 2and 3. The three days old tadpoles initially taken for the experiment had on an average (mean \pm $\mathrm{SD}, 7.28 \pm 0.37 \mathrm{~mm}$ length and $10.3 \pm 0.308 \mathrm{mg}$ body weight). After 35 days the tadpoles in control reached a length of $32.3 \pm 0.57 \mathrm{~mm}$, where as during the same period the tadpoles exposed to $0.25,0.30$ and $0.35 \mathrm{ppm}$ were respectively reached $28.78 \pm 0.43,28.1 \pm 0.29$ and $25.36 \pm$ $0.65 \mathrm{~mm}$ in their length. This showed that compared to the control condition the length was decreased by $7.8 \%, 13 \%$ and $21.4 \%$ in $0.25,0.30$ and $0.35 \mathrm{mg} \mathrm{l}^{-}$, respectively. Like length, the body weight of tadpoles after 35 days decreased about $6.03,6.74$ and $8.8 \%$ respectively. The two way analysis of variance (ANOVA) test was conducted to compare the difference in length and body weight of $L$. limnocharis tadpoles exposed to different concentrations of monocrotophos taking 35 days of development into consideration. ANOVA test also indicated significant decrease in length and body weight causing delay in tadpole growth. Besides significant decrease in length and body weight, a delay in tadpole growth was also noticed exposed to monocrotophos. The hind limbs emerged on $15^{\text {th }}, 21^{\text {st }}$ and $24^{\text {th }}$ day and the fore limb developed on $13^{\text {th }}, 31^{\text {st and }} 35^{\text {th }}$ day respectively in $0.25,0.30$ and $0.35 \mathrm{mg} \mathrm{l}^{-}$concentration of monocrotophos. As a result of which metamorphic climax was reached by 38,41 and 44 days in the three different concentrations respectively with compared to 35 days in control condition.

Table 2. Effect of Monocrotophos(Amicron 36\% SL) on the development (Total length in $\mathrm{mm}$ ) of Limnonectis limnocharis tadpoles during metamorphosis

\begin{tabular}{|c|c|c|c|c|}
\hline \multirow{2}{*}{ Days } & \multicolumn{4}{|c|}{ Concentration of monocrotophos exposed } \\
\hline & 0ppm & $0.25 \mathrm{ppm}$ & $0.30 \mathrm{ppm}$ & $0.35 \mathrm{ppm}$ \\
\hline 3 & $7.28 \pm 0.37$ & $7.28 \pm 0.37 *$ & $7.28 \pm 0.37 *$ & $7.28 \pm 0.37 *$ \\
\hline 6 & $21.7 \pm 0.367$ & $\begin{array}{c}20.22 \pm 0.277 * \\
(-6.8)\end{array}$ & $\begin{array}{c}17.7 \pm 0.717 * \\
(-18.43)\end{array}$ & $\begin{array}{c}15.82 \pm 0.717 * \\
(-27.09)\end{array}$ \\
\hline 9 & $24.0 \pm 0.1$ & $\begin{array}{c}22.34 \pm 0.415^{*} \\
(-6.9)\end{array}$ & $\begin{array}{c}19.58 \pm 0.676^{*} \\
(-18.41)\end{array}$ & $\begin{array}{c}16.26 \pm 0.618^{*} \\
(-32.2)\end{array}$ \\
\hline 12 & $25.5 \pm 0.533$ & $\begin{array}{c}23.24 \pm 0.391 * \\
(-8.8)\end{array}$ & $\begin{array}{c}21.14 \pm 0.336^{*} \\
(-17.0)\end{array}$ & $\begin{array}{c}17.78 \pm 0.443 * \\
(-30.2)\end{array}$ \\
\hline 15 & $28.8 \pm 0.836$ & $\begin{array}{c}27.82 \pm 0.311^{*} \\
(-3.4)\end{array}$ & $\begin{array}{c}25.30 \pm 0.57^{*} \\
(-12.15)\end{array}$ & $\begin{array}{c}20.96 \pm 0.456 * \\
(-27.22)\end{array}$ \\
\hline 18 & $30.4 \pm 0.717$ & $\begin{array}{c}27.84 \pm 0.502^{*} \\
(-8.4)\end{array}$ & $\begin{array}{c}25.76 \pm 0.487^{*} \\
(-15.2)\end{array}$ & $\begin{array}{c}21.6 \pm 0.651 * \\
(-28.9)\end{array}$ \\
\hline 21 & $30.44 \pm 0.770$ & $\begin{array}{c}28.027 \pm 0.570^{*} \\
(-7.92)\end{array}$ & $\begin{array}{c}26.14 \pm 0.415^{*} \\
(-14.1)\end{array}$ & $\begin{array}{c}22.9 \pm 0.463^{*} \\
(-24.7)\end{array}$ \\
\hline 24 & $30.40 \pm 0.717$ & $\begin{array}{c}28.46 \pm 0.676^{*} \\
(-6.3)\end{array}$ & $\begin{array}{c}26.14 \pm 0.336^{*} \\
(-14.0)\end{array}$ & $\begin{array}{c}23.18 \pm 0.571^{*} \\
(-23.7)\end{array}$ \\
\hline 27 & $30.56 \pm 0.696$ & $\begin{array}{c}28.60 \pm 0.651 * \\
(-6.4)\end{array}$ & $\begin{array}{c}27.1 \pm 0.339^{*} \\
(-11.3) \\
\end{array}$ & $\begin{array}{c}24.14 \pm 0.336 * \\
(-21.0)\end{array}$ \\
\hline 30 & $30.72 \pm 0.501$ & $\begin{array}{c}28.90 \pm 0.418^{*} \\
(-5.9) \\
\end{array}$ & $\begin{array}{c}27.50 \pm 0.367 * \\
(-10.4) \\
\end{array}$ & $\begin{array}{c}24.5 \pm 0.43 * \\
(-20.2) \\
\end{array}$ \\
\hline 33 & $31.02 \pm 0.370$ & $\begin{array}{c}29.10 \pm 0.651^{*} \\
(-6.1)\end{array}$ & $\begin{array}{c}27.42 \pm 0.454 * \\
(-11.6)\end{array}$ & $\begin{array}{c}24.9 \pm 0.254^{*} \\
(-19.7)\end{array}$ \\
\hline 35 & $\begin{array}{c}32.3 \pm 0.570 \\
(\mathrm{MC})\end{array}$ & $\begin{array}{c}28.78 \pm 0.438^{*} \\
(-7.8) \\
\end{array}$ & $\begin{array}{c}28.1 \pm 0.294^{*} \\
(-13.0) \\
\end{array}$ & $\begin{array}{c}25.36 \pm 0.650 * \\
(-21.4)\end{array}$ \\
\hline 38 & & $\begin{array}{c}30.98 \pm 0.501^{*} \\
(\mathrm{MC})\end{array}$ & $\begin{array}{c}28.02 \pm 0.526^{*} \\
\text { (MC) }\end{array}$ & $25.82 \pm 0.715^{*}$ \\
\hline 41 & & & $\begin{array}{c}28.18 \pm 0.294 * \\
\text { (MC) }\end{array}$ & $26.26 \pm 0.736^{*}$ \\
\hline
\end{tabular}

Data are presented as Mean \pm SD of 5 replicates.* indicate $\mathrm{p}<0.05$ in comparison to control $(0 \mathrm{ppm})$. MC: metamorphic climax. The value in the parentheses indicates the percentage increase/decrease over control. 
Table 3. Effect of Monocrotophos(Amicron 36\% SL) on the development (total body weight in mg) of Limnonectis limnocharis tadpoles during metamorphosis.

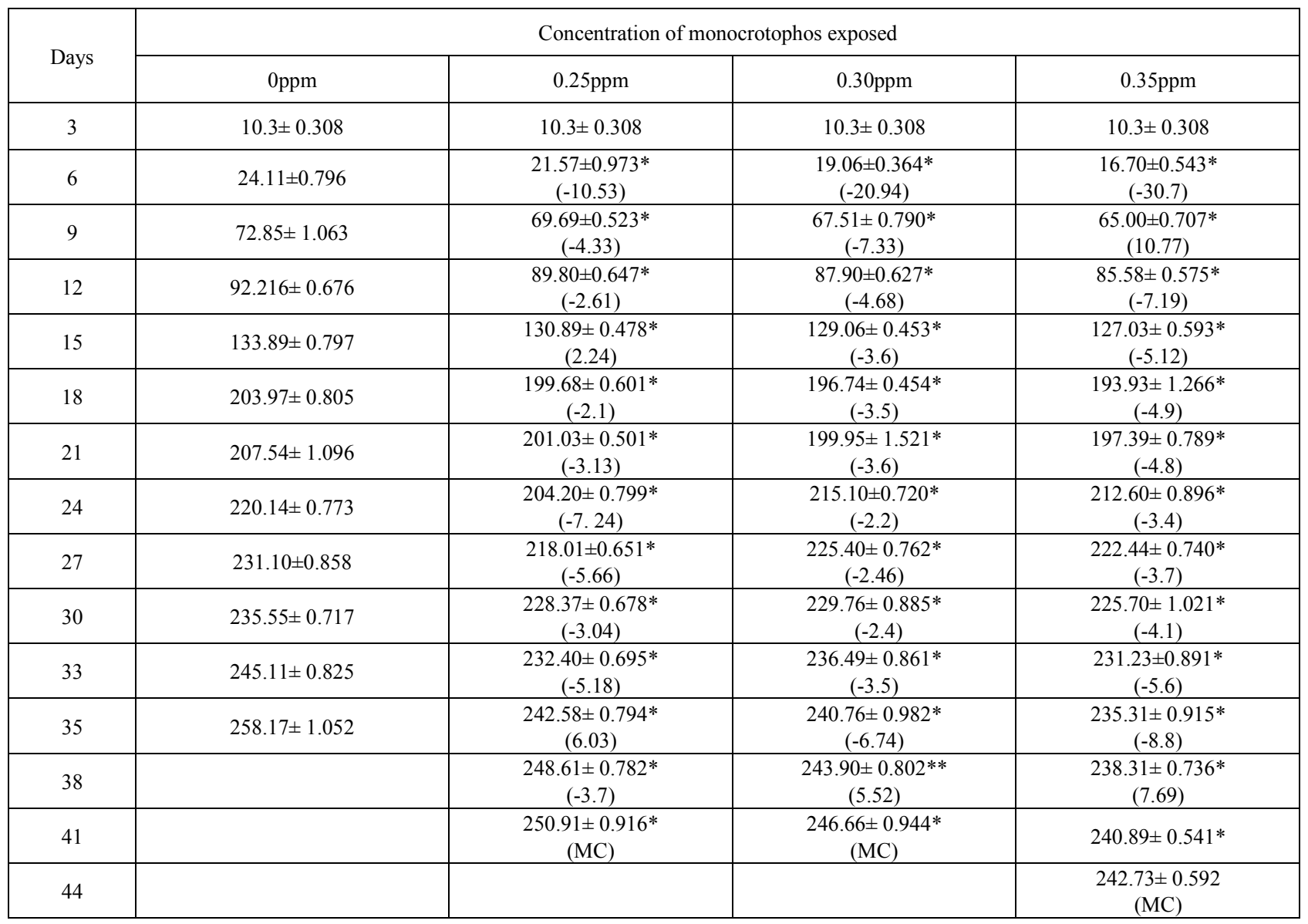

Data are presented as Mean \pm SD of 5 replicates.* indicate $\mathrm{p}<0.05$ in comparison to control $(0$ ppm). MC: metamorphic climax. The value in the parentheses indicates the percentage increase/decrease over control.

\section{Discussion}

The susceptibility of the tadpoles and adults to the agrochemicals of various kinds has been reported by several workers. Body et al.[18] have studied the possible DDT resistance in natural population of cricket frog, Acris crepitans. They have also observed a large number of dead fauna, including the Souther cricket frog Acris gryllus, green frog Hyla cinerea, fowlers toad, Bufo woodhousiei and leopard frog Rana pipiens in ponds or nearby treated cotton fields in Misissippi delta. Mulla et al.[19] have reported that field application of endrin, dieldrin and toxaphene was fatal to the bull frog Rana catesbeiana and the toads Bufo boreas and Seaphiopus hammondii. Besides this, the adverse effect of PP, DDT on tadpoles of Rana temporaria [20], rogor on tadpoles of Rana tigerina [21-22], metacid and ekalux and tadpoles of the skipper frog Rana cyanophlyctis [23] and endosulphan, malathion and furadon on tadpoles of Rana hexadactyla [24] have also been reported.

The present work shows that the growth, duration of metamorphosis of larvae of Limnonectis limnocharis were seriously affected even at three sublethal concentrations $\left(0.25,0.30\right.$ and $\left.0.35 \mathrm{mg} \mathrm{l}^{-}\right)$of monocrotophos(Amicron $36 \%$ $\mathrm{SC})$ which was much below the $\mathrm{LC}_{50}$ value $\left(0.59 \mathrm{mg} \mathrm{l}^{-}\right)$and also the recommended agricultural rate of application (0.6 $\mathrm{mg} \mathrm{l}^{-}$). The pesticides not only affect the length of larval period but also the size at metamorphosis. This indicates that when pesticides are applied to paddy fields, many beneficial non target organisms like L. limnocharis frogs seen in these fields are most likely to be affected or victimized. This can eventually leads to adverse effects on the natural ecological balance and consequently on agriculture. From conservation and sustainability point of view, time has come to evaluate purely organic farming with organic part use of fertilizer with modern agricultural practices.

\section{Conclusion}

Application of pesticides even below the recommended dose cause ecological problems and non target beneficial species are victimized. Exposed to agro-chemicals (viz., synthetic fertilizers, pesticides, etc.) reduced survivability of tadpoles and low froglet emergence due to exposure to these agrochemicals could contribute both for decline of the species and possible associated ecological imbalance.

This finding supports that organic farming and controlled use of pesticides for conservation of frogs in the paddy field. 


\section{Acknowledgement}

The authors are thankful to Professor M.C. Dash, Former Vice-Chancellor of Sambalpur University, Odisha, India for his valuable guidance and suggestion during the research work.

\section{REFERENCES}

[1] Grist I.D.H., 1953. Rice, Longmons, Gree \&Co., London.

[2] Jaiswal P.L., Wadhwani A.M., 1984. A handbook on Agriculture. ICAR Publication, New Delhi, pp 1303

[3] Mc Connell, L.L., LeNoir, J.S., Datta, S., Seiber, J.N., (1998), Wet deposition of current-use pesticides in the Sierra Nevada Mountain range, California, USA. Environmental Toxicology and Chemistry, 17,pp 19081916.

[4] Brown AWA. 1987. Ecology of pesticides. Ed. A. WileyInterscience Publication, John Wiley and Sons, New York

[5] Edward C.A., 1974. Persistent pesticides in the environment, 2nd Edn. C.R.C. Monosci Ser Buterwork, London

[6] Evan P.R., 1974 Global transport of pesticides by birds. Cbem Ind(NY) 197-199

[7] Blaustein A.R. and Wake D.B., 1990. Declining amphibian population, A global phenomenon. Trends in Ecology and Evolution, 5, 203-204

[8] Bruton J.M. and Linkens G.E., 1975.Salamander population and biomass on the Hubbard Brook experimental forest, New Hampshire, Copeia, 541-546

[9] Dickman N., 1968. The effect of grazing by tadpoles on the structure of a periphyton community. Ecology, 49, 1188-1190

[10] Seale D.B., 1980. Influence of amphibian larvae on primary production, nutrient flux and competition in a pond ecosystem. Ecology, 61, 1531-1550

[11] Dash M.C.and Mahanta J.K., 1993. Quantitative analysis of the community structure of tropical amphibian assemblages and its significance to conservation. J. Biosci, 18(1), 121-139

[12] Blaustein A.R., Wake D.B. and Sousa P., 1994. Amphibian decline judging stability, persistence and susceptibility of populations to local and global extinctions. Conservation Biology, 8, 60-71

[13] Blaustein A.R. and Wake D.B., 1995. The puzzle of declining amphibian population. Scientific American, 4, 56-61

[14] Wake D.B., 1991. Declining amphibian population. Science, 253,260

[15] Dash M.C. and Hota A.K., 1980. Density effects on the survival, growth rate and metamorphosis of Rana tigerina tadpoles. Ecology, 61(5), 1025-1028

[16] Finney D.J., 1971. Probit analysis, Cambridge University Press (3rd Ed.), Cambridge

[17] Nace G.W. and Richards C.M., 1972. Living frogs.3. Tadpoles. Carolina Tips XXXV, No 12, Burlington, North Carolina, USA, 45-46

[18] Boyd C.E., Vinson S.M. and Ferguson D.E., 1963. Possible DDT resistance in two species of frogs. Copeia, 2, 426-429

[19] Mulla M.A., Issac L.W. and Xelord, A., 1963. Field studies on the effect of insecticides on some aquatic wildlife species. J. Econ. Ent, 56, 181-188

[20] Cooke A.S., 1970.The effect of PP DDT on tadpoles of the common fog R. catesbeiana. Ecology, 60, 739-749

[21] Dutta S.K. and Mohanty-Hejamadi P., 1978. Life history and pesticide susceptible embryonic stages of the Indian bull frog Rana tigerina (Daudin). Indian J of Exp Biol, 16(6), 727-729

[22] Mohanty-Hejmadi P. and Dutta S.K., 1981.Effect of some pesticides on the development of the Indian bull frog Rana tigerina. Environ Pollut, 24, 145-161

[23] Noor Alam M.D., 1989.Toxicity of metacid and ekalux to tadpoles of skipper frog Rana cyanophlyctis. J. Ecobiology, $3,163-167$

[24] Andrew M.I. and George S., 1991. Toxic effect of pesticides on tadpoles of frog Rana hexadactyla. J. Ecotoxicol. Environment, 1(2), 142-147 